NASA/TM-2004-213400

\title{
Low Earth Orbital Atomic Oxygen Interactions With Spacecraft Materials
}

Bruce A. Banks, Kim K. de Groh, and Sharon K. Miller

Glenn Research Center, Cleveland, Ohio 
Since its founding, NASA has been dedicated to the advancement of aeronautics and space science. The NASA Scientific and Technical Information (STI) Program Office plays a key part in helping NASA maintain this important role.

The NASA STI Program Office is operated by Langley Research Center, the Lead Center for NASA's scientific and technical information. The NASA STI Program Office provides access to the NASA STI Database, the largest collection of aeronautical and space science STI in the world. The Program Office is also NASA's institutional mechanism for disseminating the results of its research and development activities. These results are published by NASA in the NASA STI Report Series, which includes the following report types:

- $\quad$ TECHNICAL PUBLICATION. Reports of completed research or a major significant phase of research that present the results of NASA programs and include extensive data or theoretical analysis. Includes compilations of significant scientific and technical data and information deemed to be of continuing reference value. NASA's counterpart of peerreviewed formal professional papers but has less stringent limitations on manuscript length and extent of graphic presentations.

- TECHNICAL MEMORANDUM. Scientific and technical findings that are preliminary or of specialized interest, e.g., quick release reports, working papers, and bibliographies that contain minimal annotation. Does not contain extensive analysis.

- CONTRACTOR REPORT. Scientific and technical findings by NASA-sponsored contractors and grantees.
- CONFERENCE PUBLICATION. Collected papers from scientific and technical conferences, symposia, seminars, or other meetings sponsored or cosponsored by NASA.

- SPECIAL PUBLICATION. Scientific, technical, or historical information from NASA programs, projects, and missions, often concerned with subjects having substantial public interest.

- TECHNICAL TRANSLATION. Englishlanguage translations of foreign scientific and technical material pertinent to NASA's mission.

Specialized services that complement the STI Program Office's diverse offerings include creating custom thesauri, building customized databases, organizing and publishing research results ... even providing videos.

For more information about the NASA STI Program Office, see the following:

- Access the NASA STI Program Home Page at http://www.sti.nasa.gov

- E-mail your question via the Internet to help@sti.nasa.gov

- Fax your question to the NASA Access Help Desk at 301-621-0134

- Telephone the NASA Access Help Desk at 301-621-0390

- Write to:

NASA Access Help Desk

NASA Center for AeroSpace Information 7121 Standard Drive

Hanover, MD 21076 
NASA/TM-2004-213400

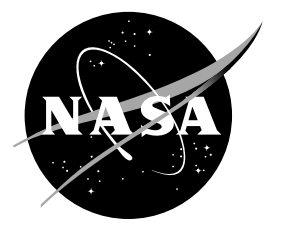

\section{Low Earth Orbital Atomic Oxygen Interactions With Spacecraft Materials}

Bruce A. Banks, Kim K. de Groh, and Sharon K. Miller

Glenn Research Center, Cleveland, Ohio

Prepared for the

2004 Fall Meeting

sponsored by the Materials Research Society

Boston, Massachusetts, November 29-December 3, 2004

National Aeronautics and

Space Administration

Glenn Research Center 
Available from

NASA Center for Aerospace Information 7121 Standard Drive

Hanover, MD 21076
National Technical Information Service 5285 Port Royal Road Springfield, VA 22100

Available electronically at http://gltrs.grc.nasa.gov 


\title{
Low Earth Orbital Atomic Oxygen Interactions With Spacecraft Materials
}

\author{
Bruce A. Banks, Kim K. de Groh, and Sharon K. Miller \\ National Aeronautics and Space Administration \\ Glenn Research Center \\ Cleveland, Ohio 44135
}

\begin{abstract}
Atomic oxygen, formed in Earth's thermosphere, interacts readily with many materials on spacecraft flying in low Earth orbit (LEO). All hydrocarbon based polymers and graphite are easily oxidized upon the impact of $\sim 4.5 \mathrm{eV}$ atomic oxygen as the spacecraft ram into the residual atmosphere. The resulting interactions can change the morphology and reduce the thickness of these materials. Directed atomic oxygen erosion will result in the development of textured surfaces on all materials with volatile oxidation products. Examples from space flight samples are provided. As a result of the erosive properties of atomic oxygen on polymers and composites, protective coatings have been developed and are used to increase the functional life of polymer films and composites that are exposed to the LEO environment. The atomic oxygen erosion yields for actual and predicted LEO exposure of numerous materials are presented. Results of inspace exposure of vacuum deposited aluminum protective coatings on polyimide Kapton indicate high rates of degradation are associated with aluminum coatings on both surfaces of the Kapton. Computational modeling predictions indicate that less trapping of the atomic oxygen occurs, with less resulting damage, if only the space-exposed surface is coated with vapor deposited aluminum rather than having both surfaces coated.
\end{abstract}

\section{Introduction}

Although knowledge of atomic oxygen existed in the early days of space exploration, an awareness of the damaging effects on spacecraft materials was not well known until the Space Shuttle began flying missions at much lower altitudes in low Earth orbit (LEO) [1].

Early in-space observation that the residual atmosphere was interacting with spacecraft surfaces came in part as a result of comparison of day and night pictures of the space shuttle, as shown in Figure 1, where the glow from de-excitation atoms and molecules leaving shuttle surfaces oriented in the ram (forward facing) direction are shown [ 2 and 3]. A second indication of LEO atomic oxygen interactions came from observations of increases in the diffuse reflectance of polymers such as polyimide Kapton $\mathrm{H}$ due to surface texturing. Such observations lead to further tests which documented the rate of atomic oxygen erosion of commonly used spacecraft polymers, and resulting modifications to LEO spacecraft design in efforts to enable spacecraft to be durable to the LEO atomic oxygen environment.

This paper provides an overview of the LEO atomic oxygen environment, its interaction with spacecraft materials, approaches for protection from atomic oxygen, and on-orbit and computational results of protection methods. 


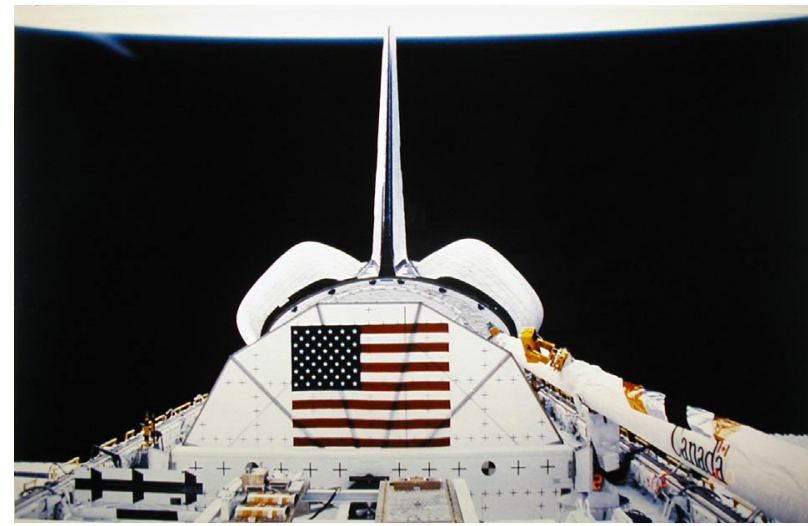

a. In sunlight

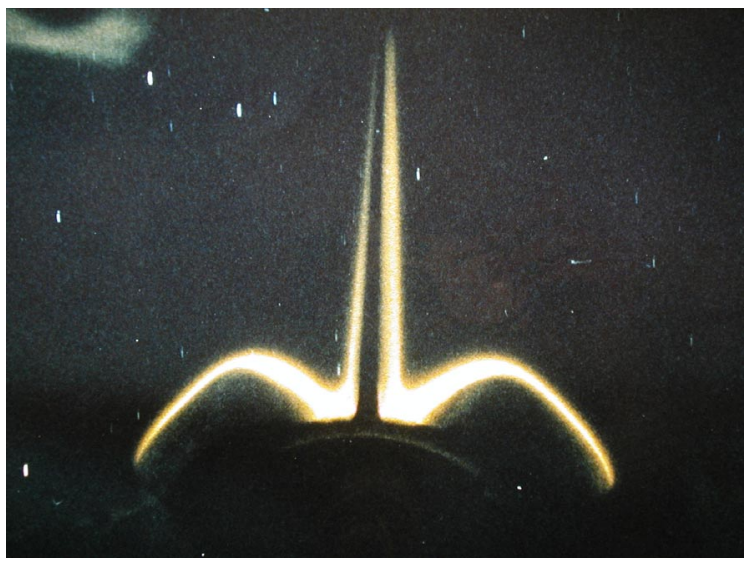

b. At night

Figure 1. Space shuttle with the bay oriented in the direction of travel (ram direction).

\section{The LEO Atomic Oxygen Environment}

Atomic oxygen, in LEO, is formed by photodissociation of the residual diatomic oxygen that is exposed to the sun's ultraviolet radiation of wavelengths of less than $243 \mathrm{~nm}$, in an environment where the atmospheric density is to low for competitive recombination processes to form ozone, diatomic oxygen or oxides of nitrogen. As a result, atomic oxygen is typically the most abundant specie between the altitudes of 180 and $650 \mathrm{~km} \mathrm{[1],} \mathrm{as} \mathrm{shown} \mathrm{in} \mathrm{Figure} 2$.

As one goes up in altitude, the average molecular weight decreases and the temperature gradually increases as shown in Figures 3 and 4, respectively [1].

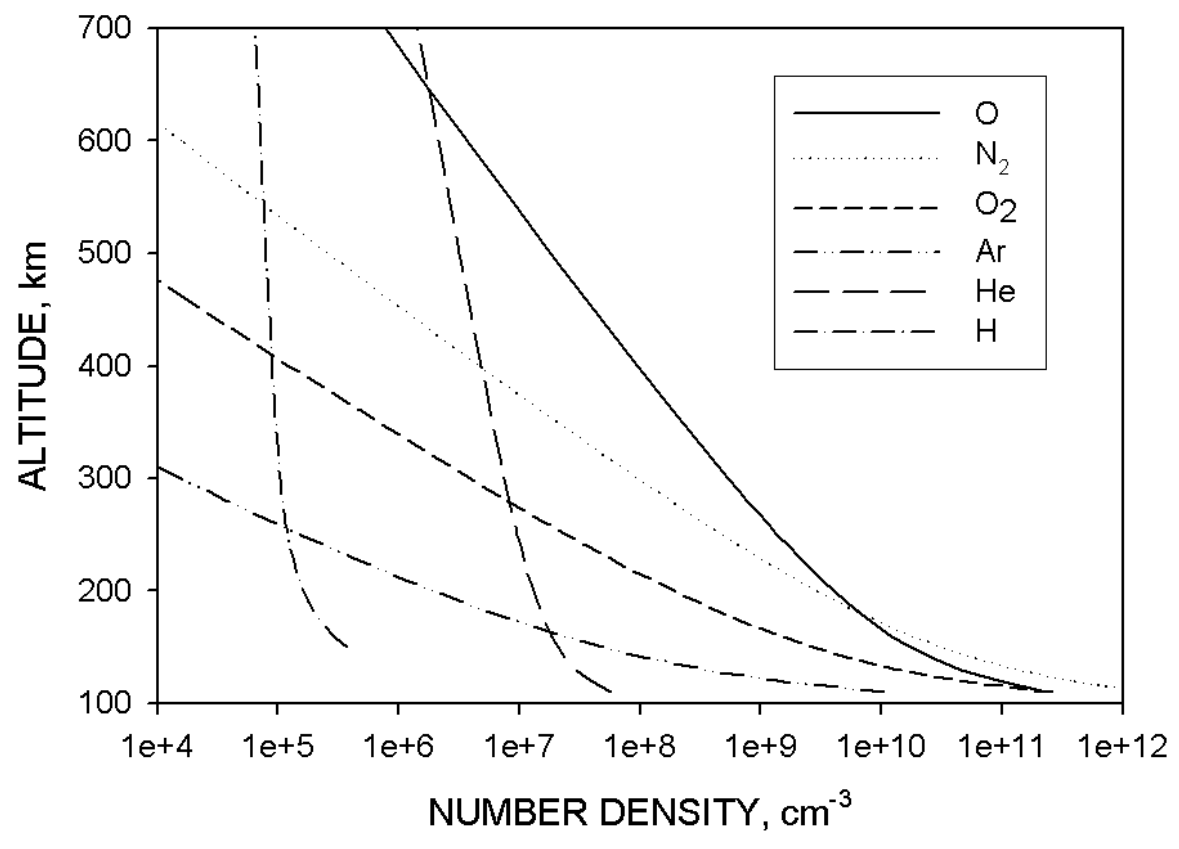

Figure 2. Density of atmospheric constituents as a function of altitude [1]. 


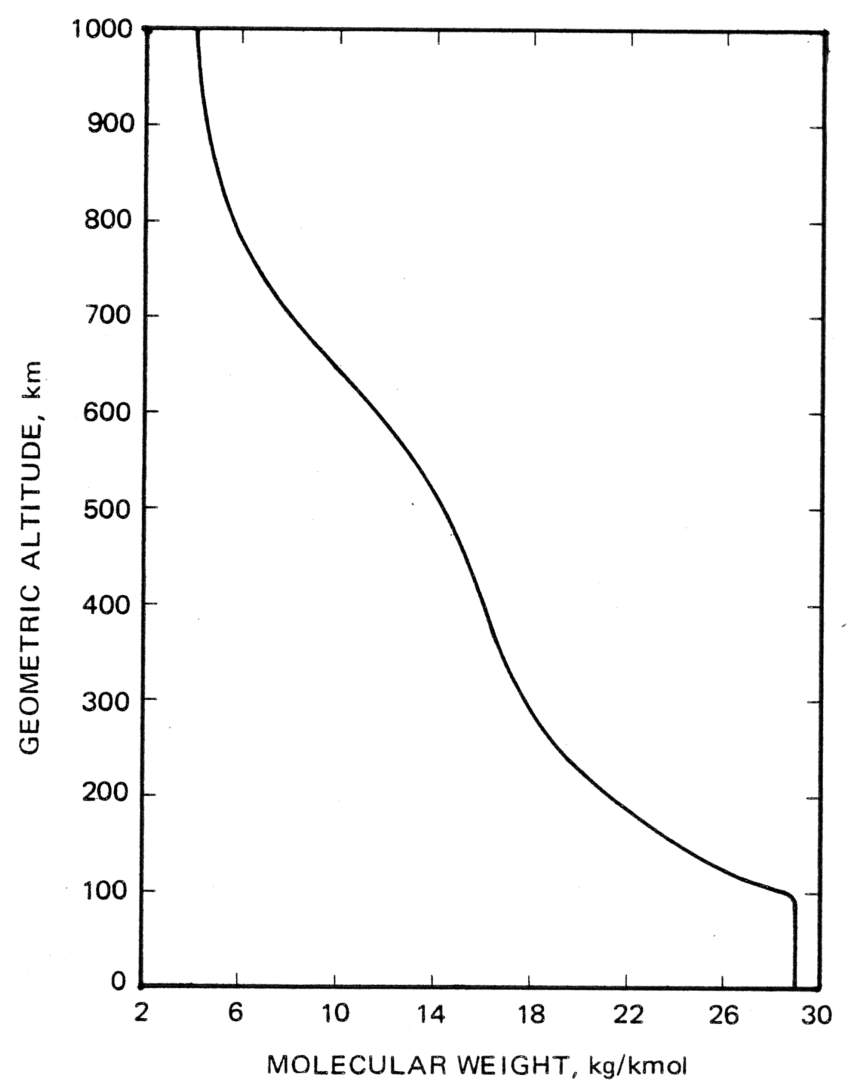

Figure 3. Average molecular weight as a function of altitude [1].

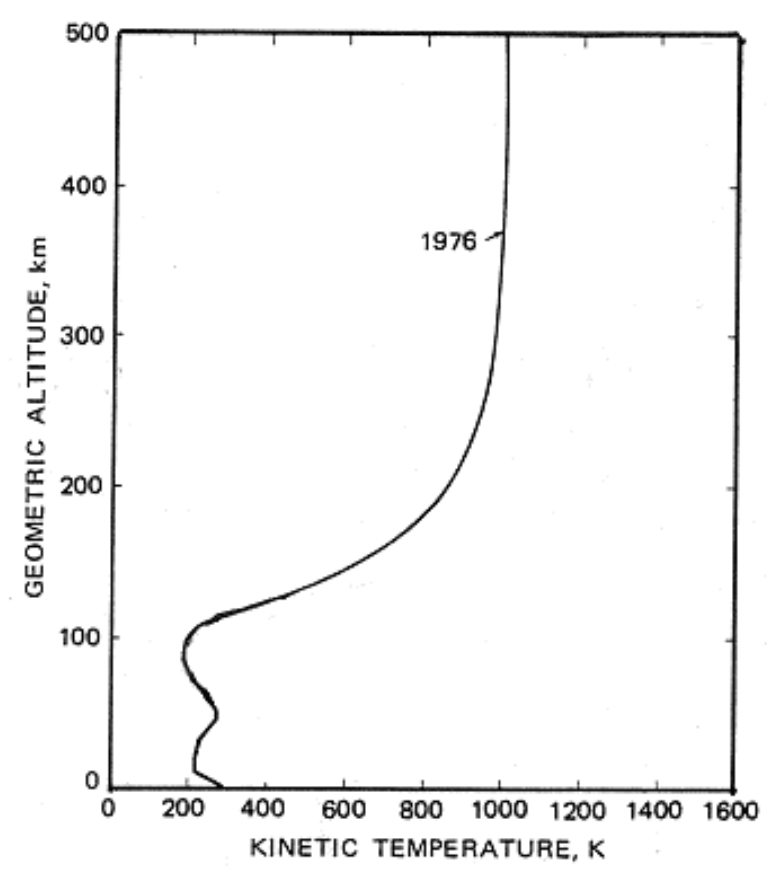

Figure 4. Kinetic temperature of LEO atomic oxygen as a function of altitude [1]. 
The Earth's thermosphere co-rotates with the Earth giving atomic oxygen a velocity in the direction of the Earth's rotation. However, the orbital velocity of spacecraft is much greater and through most parts of an orbit is at an inclined angle to the equatorial plane. This orbital velocity vector, the Earth's co-rotation vector, and the random thermal velocity of the hot Maxwellian atomic oxygen gas causes a distribution of the arrival flux with angle of attack as well as a statistical variation in the energy atomic oxygen as it impacts spacecraft surfaces, as shown in Figures 5 and 6, respectively. Although Figure 6 is for circular orbits, highly inclined orbits would result in much greater impact energies.

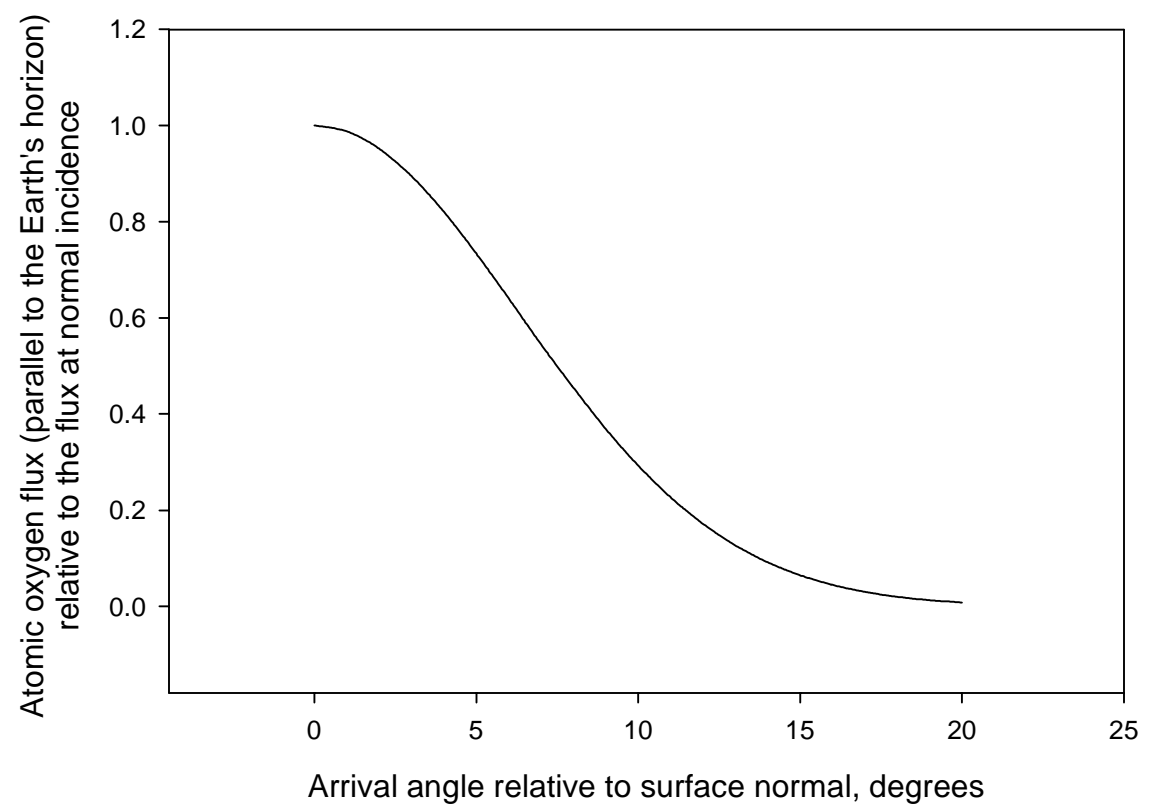

Figure 5. LEO atomic oxygen arrival flux versus arrival angle from ram direction for surfaces perpendicular to the ram direction.

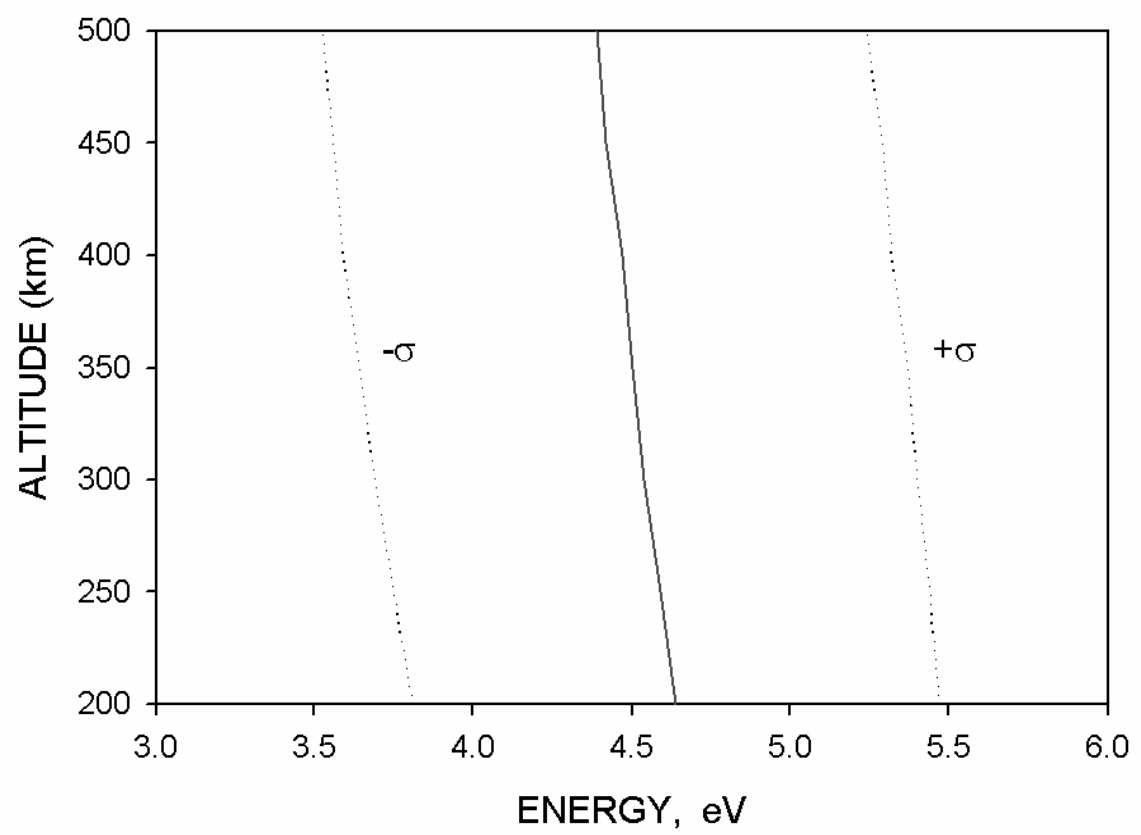

Figure 6. LEO Atomic oxygen energy versus orbital altitude for $28.5^{\circ}$ inclined circular orbits. 


\section{Organic Materials Interaction With Atomic Oxygen}

LEO atomic oxygen is a highly reactive form of oxygen which also has sufficient energy to break chemical bonds. As a result, it is thought to have a probability of approximately $14 \%$ for reacting upon initial impact with materials such as carbon [4] or polyimide Kapton H [5]. The amount of erosion of polymers is equal to the product of the erosion yield of the polymer and the atomic oxygen fluence. Where the erosion yield is the number of cubic centimeters of the polymer that is eroded per incident oxygen atom $\left(\mathrm{cm}^{3} /\right.$ atom) and the atomic oxygen fluence is the number of atoms impacting per square centimeter $\left(\right.$ atoms $/ \mathrm{cm}^{2}$ ). The atomic oxygen erosion yields for numerous materials are listed in Table 1.

Table 1. Atomic oxygen erosion yields for various materials.

\begin{tabular}{|c|c|c|c|c|c|}
\hline \multirow{2}{*}{ Material } & \multirow[t]{2}{*}{ Abbrev. } & \multirow{2}{*}{$\begin{array}{l}\text { Trade } \\
\text { Names }\end{array}$} & \multicolumn{2}{|c|}{$\begin{array}{c}\text { Predicted Erosion Yield } \\
\text { in LEO by Different } \\
\text { Correlations [7] } \\
\left(\times 10^{-24} \mathrm{~cm}^{3} / \text { atom }\right)\end{array}$} & \multirow{2}{*}{$\begin{array}{l}\text { Measured Erosion } \\
\text { Yield in LEO } \\
\left(\times \mathbf{1 0}^{-24} \mathrm{~cm}^{3} / \text { atom }\right) \\
\text { and references }\end{array}$} \\
\hline & & & $\begin{array}{c}\gamma^{\prime} \text { mod- } \\
\text { Correlation }\end{array}$ & $\begin{array}{l}\text { Oxidation } \\
\text { Index } \\
\text { Correlation }\end{array}$ & \\
\hline $\begin{array}{l}\text { Acrylonitrile } \\
\text { butadiene styrene }\end{array}$ & ABS & $\begin{array}{l}\text { Cycolac; } \\
\text { Lustran }\end{array}$ & 2.3 & 3.1 & \\
\hline Carbon & & & & & $0.9-1.7[5]$ \\
\hline $\begin{array}{l}\text { Carbon (highly } \\
\text { oriented pyrolytic } \\
\text { graphite) }\end{array}$ & HOPG & Graphite & 1.0 & 1.3 & $\begin{array}{l}1.04-1.2[6] ; 1.2-1.7 \\
{[7] ; 1.2[5]}\end{array}$ \\
\hline $\begin{array}{l}\text { Carbon (pyrolytic } \\
\text { polycrystalline) }\end{array}$ & PG & Graphite & & & $0.61-1.2[6] ; 1.2[5]$ \\
\hline $\begin{array}{l}\text { Carbon (single } \\
\text { crystal natural Class } \\
\text { IIA diamond) }\end{array}$ & & Diamond & & & $\begin{array}{l}0.0000 \pm 0.000023[6] ; \\
0.021[5]\end{array}$ \\
\hline Cellulose acetate & $\mathrm{CA}$ & $\begin{array}{l}\text { Cellidor; } \\
\text { Tenite } \\
\text { Acetate }\end{array}$ & 6.8 & $3.2(5.2)$ & \\
\hline Cellulose nitrate & $\mathrm{CN}$ & $\begin{array}{l}\text { Celluloid; } \\
\text { Xylonite }\end{array}$ & 13.1 & & \\
\hline $\begin{array}{l}\text { Crystalline } \\
\text { polyvinylfluoride } \\
\text { w/white pigment }\end{array}$ & PVF & $\begin{array}{l}\text { White } \\
\text { Tedlar }\end{array}$ & 3.4 & 3.0 & $0.29[6] ; 3.2[7]$ \\
\hline $\begin{array}{l}\text { Diallyl diglycol and } \\
\text { triallyl cyanurate }\end{array}$ & $\mathrm{ADC}$ & CR-39 & 6.1 & 4.6 & $6.1[7]$ \\
\hline Epoxide or epoxy & $\mathrm{EP}$ & $\begin{array}{l}\text { Epoxy } \\
\text { resin }\end{array}$ & 2.9 & 2.3 & $\begin{array}{l}2.7 \text { [7] Epoxy Resin } \\
5208 ; 1.7 \text { [5] }\end{array}$ \\
\hline $\begin{array}{l}\text { Ethylene vinyl } \\
\text { acetate copolymer }\end{array}$ & EVAC & Elvax & 3.9 & 3.5 & \\
\hline $\begin{array}{l}\text { Ethylene vinyl } \\
\text { alcohol copolymer }\end{array}$ & $\begin{array}{l}\text { EVAL } \\
\text { (EVOH) }\end{array}$ & Eval & 3.5 & 3.0 & \\
\hline $\begin{array}{l}\text { Ethylene/propylene/ } \\
\text { diene }\end{array}$ & $\begin{array}{c}\text { EPTR } \\
(\text { EPDM })\end{array}$ & $\begin{array}{l}\text { Nordel; } \\
\text { Keltan }\end{array}$ & 2.9 & 3.0 & \\
\hline
\end{tabular}


Table 1. Atomic oxygen erosion yields for various materials (continued).

\begin{tabular}{|c|c|c|c|c|c|}
\hline \multirow{2}{*}{ Material } & \multirow{2}{*}{ Abbrev. } & \multirow{2}{*}{$\begin{array}{c}\text { Trade } \\
\text { Names }\end{array}$} & \multicolumn{2}{|c|}{$\begin{array}{c}\text { Predicted Erosion Yield } \\
\text { in LEO by Different } \\
\text { Correlations [7] } \\
\left(\times 10^{-24} \mathbf{c m}^{3} / \text { atom }\right)\end{array}$} & \multirow{2}{*}{$\begin{array}{l}\text { Measured Erosion } \\
\text { Yield in LEO } \\
\left(\times 10^{-24} \mathrm{~cm}^{3} / \text { atom }\right) \\
\text { and references }\end{array}$} \\
\hline & & & $\begin{array}{c}\gamma^{\prime} \text { mod- } \\
\text { Correlation }\end{array}$ & $\begin{array}{c}\text { Oxidation } \\
\text { Index } \\
\text { Correlation }\end{array}$ & \\
\hline $\begin{array}{l}\text { Fluorinated ethylene } \\
\text { propylene }\end{array}$ & FEP & $\begin{array}{l}\text { Teflon } \\
\text { FEP }\end{array}$ & 0.0 & $\mathrm{n} / \mathrm{a}$ & $\begin{array}{l}0.337 \pm 0.005 *[6] ; 0.35 \\
{[6] ; 0.03-0.05[7] ; 0.037} \\
{[6] ; 0.0-<0.05[5]}\end{array}$ \\
\hline $\begin{array}{l}\text { Halar ethylene- } \\
\text { chlorotrifluoro- } \\
\text { ethylene }\end{array}$ & ECTFE & Halar & 2.0 & $\mathrm{n} / \mathrm{a}$ & $2.0-2.1[6] ; 1.9[7]$ \\
\hline $\begin{array}{l}\text { Melamine } \\
\text { formaldehyde resin }\end{array}$ & MF & $\begin{array}{l}\text { Melmex; } \\
\text { Melopas }\end{array}$ & 3.4 & & \\
\hline $\begin{array}{l}\text { Phenol } \\
\text { formaldehyde resin }\end{array}$ & $\mathrm{PF}$ & $\begin{array}{l}\text { Bakelite; } \\
\text { Plenco; } \\
\text { Durex }\end{array}$ & 2.3 & 2.5 & \\
\hline $\begin{array}{l}\text { Poly-(p-phenylene } \\
\text { terephthalamide) }\end{array}$ & $\begin{array}{l}\text { PPD-T } \\
\text { (PPTA) }\end{array}$ & Kevlar 29 & 2.5 & 2.9 & $\begin{array}{l}1.5 \pm 0.5 \text { Kevlar } 29[6] \\
\text { 2.1-4.1 Kevlar } 29[7] ; \\
4.0 \pm 0.5 \text { Kevlar } 49[6] \\
\text { 2.1-4.1 Kevlar } 49[7]\end{array}$ \\
\hline Polyacrylonitrile & PAN & $\begin{array}{l}\text { Acrilan; } \\
\text { Barex; } \\
\text { Orlon }\end{array}$ & 2.5 & 4.5 & \\
\hline $\begin{array}{l}\text { Polyamide } 6 \text { or } \\
\text { nylon } 6\end{array}$ & PA 6 & $\begin{array}{l}\text { Caprolan; } \\
\text { Akulon K; } \\
\text { Ultramid }\end{array}$ & 3.7 & 3.6 & $2.8 \pm 0.2[6] ; 4.2[7]$ \\
\hline $\begin{array}{l}\text { Polyamide } 66 \text { or } \\
\text { nylon } 66\end{array}$ & PA 66 & $\begin{array}{l}\text { Maranyl; } \\
\text { Zytel; } \\
\text { Durethane }\end{array}$ & 3.7 & 3.6 & $2.8 \pm 0.2[6]$ \\
\hline Polybenzimidazole & PBI & Celazole & 1.9 & 1.8 & $1.5[7] ; 1.5[5]$ \\
\hline Polycarbonate & $\mathrm{PC}$ & $\begin{array}{l}\text { Lexan; } \\
\text { Makrolon }\end{array}$ & 2.9 & 3.2 & 2.9 [7]; $6.0[5]$ \\
\hline $\begin{array}{l}\text { Polychlorotrifluoro- } \\
\text { ethylene }\end{array}$ & PCTFE & $\begin{array}{l}\text { Kel-F; } \\
\text { Aclar }\end{array}$ & 1.0 & $\mathrm{n} / \mathrm{a}$ & $1.97 \pm 0.12 *[6] ; 0.9[7]$ \\
\hline $\begin{array}{l}\text { Polyetheretherkey- } \\
\text { tone }\end{array}$ & PEEK & $\begin{array}{l}\text { Victrex } \\
\text { PEEK; } \\
\text { Hostatec } \\
\end{array}$ & 2.3 & 2.1 & $\begin{array}{l}3.7 \pm 1.0[6] ; 2.3[6] \\
3.2-4.5[7]\end{array}$ \\
\hline Polyethylene & $\mathrm{PE}$ & $\begin{array}{l}\text { Alathon; } \\
\text { Lupolen; } \\
\text { Hostalen }\end{array}$ & 3.0 & 4.2 & $\begin{array}{l}3.97 \pm 0.23[6] ; 3.2-4.5 \\
{[7] ; 3.3[5] ; 3.7[5]}\end{array}$ \\
\hline Polyethylene oxide & PEO & $\begin{array}{l}\text { Alkox; } \\
\text { Polyox }\end{array}$ & 7.1 & 5.8 & \\
\hline
\end{tabular}


Table 1. Atomic oxygen erosion yields for various materials (continued).

\begin{tabular}{|c|c|c|c|c|c|}
\hline \multirow{2}{*}{ Material } & \multirow[t]{2}{*}{ Abbrev. } & \multirow{2}{*}{$\begin{array}{l}\text { Trade } \\
\text { Names }\end{array}$} & \multicolumn{2}{|c|}{$\begin{array}{l}\text { Predicted Erosion Yield } \\
\text { in LEO by Different } \\
\text { Correlations [7] } \\
\left(\times \mathbf{1 0}^{-24} \mathbf{c m}^{3} / \text { atom }\right)\end{array}$} & \multirow{2}{*}{$\begin{array}{l}\text { Measured Erosion } \\
\text { Yield in LEO } \\
\left(\times 10^{-24} \mathrm{~cm}^{3} / \text { atom }\right) \\
\text { and references }\end{array}$} \\
\hline & & & $\begin{array}{c}\gamma^{\prime} \text { mod- } \\
\text { Correlatio } \\
n\end{array}$ & $\begin{array}{c}\text { Oxidation } \\
\text { Index } \\
\text { Correlation }\end{array}$ & \\
\hline $\begin{array}{l}\text { Polyethylene } \\
\text { terephthalate }\end{array}$ & PET & $\begin{array}{l}\text { Mylar; } \\
\text { Tenite }\end{array}$ & 3.5 & 3.1 & $\begin{array}{l}\text { 3.4-3.6 Mylar A [6]; } \\
\text { 3.4-3.7 Mylar A [5]; } 3.0 \\
\text { Mylar D [6]; 2.9-3.0 } \\
\text { Mylar D [5]; 3.4-3.9 [7]; } \\
1.5-3.9 \text { [5] }\end{array}$ \\
\hline Polyimide (PMDA) & PI & Kapton HN & 2.9 & 2.0 & $3.0[7] ; 3.0[5]$ \\
\hline Polyimide (PMDA) & PI & Kapton H & 2.9 & 2.0 & $\begin{array}{l}3.0[6] ; 2.89 \pm 0.6[6] ; \\
3.0[7] ; 3.0[5] ; 1.5-3.1 \\
{[5]}\end{array}$ \\
\hline Polyimide (PMDA) & PI & $\begin{array}{c}\text { Black } \\
\text { Kapton }\end{array}$ & & & $1.4-2.2[5]$ \\
\hline $\begin{array}{l}\text { Polymethyl } \\
\text { methacrylate }\end{array}$ & PMMA & $\begin{array}{l}\text { Plexiglas; } \\
\text { Lucite }\end{array}$ & 5.1 & 4.5 & $\begin{array}{l}6.3 \pm 0.3[6] ; 3.9-4.8 \\
{[7] ; 3.1[5]}\end{array}$ \\
\hline $\begin{array}{l}\text { Polyoxymethylene; } \\
\text { acetal; } \\
\text { polyformaldehyde }\end{array}$ & POM & $\begin{array}{c}\text { Delrin; } \\
\text { Celcon; } \\
\text { Acetal } \\
\end{array}$ & $8.0-12.0$ & 5.0 & \\
\hline Polyphenylene & PPH & & 1.8 & & \\
\hline $\begin{array}{l}\text { Polyphenylene } \\
\text { isophthalate }\end{array}$ & PPPA & Nomex & 2.5 & 2.9 & \\
\hline Polypropylene & PP & $\begin{array}{c}\text { Profax; } \\
\text { Propathene }\end{array}$ & 2.9 & 4.1 & $4.4[6]$ \\
\hline Polystyrene & PS & $\begin{array}{l}\text { Lustrex; } \\
\text { Polystyrol; } \\
\text { Styron }\end{array}$ & 2.1 & 6.0 & $4.17 \pm 0.17[6] ; 1.8[7]$ \\
\hline $\begin{array}{l}\text { Polysulphone } \\
\text { (Polysulfone) }\end{array}$ & PSU & $\begin{array}{c}\text { Udel; } \\
\text { Ultrason/S }\end{array}$ & 2.5 & $2.4-3.0$ & $2.3[6] ; 2.1[7] ; 2.4$ [5] \\
\hline $\begin{array}{l}\text { Polytetrafluoro- } \\
\text { ethylene }\end{array}$ & PTFE & $\begin{array}{l}\text { Fluon; } \\
\text { Teflon; } \\
\text { Halon }\end{array}$ & 0.0 & $\mathrm{n} / \mathrm{a}$ & $\begin{array}{l}0.20[6] ; 0.37 \pm 0.06[6] ; \\
0.03-0.05[7] ; 0.0-0.2 \\
{[5]}\end{array}$ \\
\hline Polyvinyl acetate & PVA & Elvacet & 6.2 & & \\
\hline Polyvinyl alcohol & $\mathrm{PVA}(\mathrm{L})$ & Elvanol & 7.1 & 4.1 & \\
\hline Polyvinyl fluoride & PVF & Tedlar & & & $\begin{array}{l}3.8 \text { clear }[6] ; 1.3-3.2 \\
\text { clear }[5] ; 0.05-0.6 \text { white } \\
{[5]}\end{array}$ \\
\hline
\end{tabular}


Table 1. Atomic oxygen erosion yields for various materials (concluded).

\begin{tabular}{|c|c|c|c|c|c|}
\hline \multirow{2}{*}{ Material } & \multirow{2}{*}{ Abbrev. } & \multirow{2}{*}{$\begin{array}{l}\text { Trade } \\
\text { Names }\end{array}$} & \multicolumn{2}{|c|}{$\begin{array}{c}\text { Predicted Erosion Yield } \\
\text { in LEO by Different } \\
\text { Correlations [7] } \\
\left(\times 10^{-24} \mathrm{~cm}^{3} / \text { atom }\right)\end{array}$} & \multirow{2}{*}{$\begin{array}{l}\text { Measured Erosion } \\
\text { Yield in LEO } \\
\left(\times 10^{-24} \mathrm{~cm}^{3} / \text { atom }\right) \\
\text { and references }\end{array}$} \\
\hline & & & $\begin{array}{c}\gamma^{\prime} \bmod - \\
\text { Correlation }\end{array}$ & $\begin{array}{c}\text { Oxidation } \\
\text { Index } \\
\text { Correlation }\end{array}$ & \\
\hline $\begin{array}{l}\text { Polyvinylidene } \\
\text { chloride copolymers }\end{array}$ & PVDC & Saran & 5.1 & $\mathrm{n} / \mathrm{a}$ & \\
\hline $\begin{array}{l}\text { Polyvinylidene } \\
\text { fluoride }\end{array}$ & PVDF & Kynar & 1.1 & $\mathrm{n} / \mathrm{a}$ & $0.9-1.1$ [7]; 0.6 [5] \\
\hline Polyxylylene & PX & $\begin{array}{l}\text { Parilene; } \\
\text { Parylene }\end{array}$ & 2.1 & & \\
\hline Pyrone & PR & Pyrone & 2.4 & & $2.3[7] ; 2.5$ [5] \\
\hline $\begin{array}{l}\text { Tetrafluorethylene- } \\
\text { ethylene copolymer }\end{array}$ & ETFE & Tefzel ZM & 1.1 & $\mathrm{n} / \mathrm{a}$ & $1.2[7]$ \\
\hline Urea formaldehyde & UF & $\begin{array}{l}\text { Beetle; } \\
\text { Avisco }\end{array}$ & 5.1 & 3.0 & \\
\hline
\end{tabular}

* Corrected for LDEF ram fluence of $9.09 \times 10^{21}$ atoms $/ \mathrm{cm}^{2}$

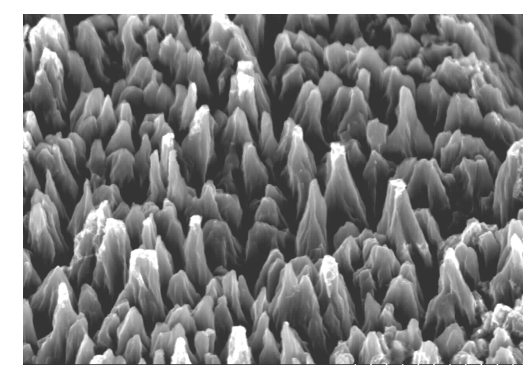

$2 \mu \mathrm{m}$

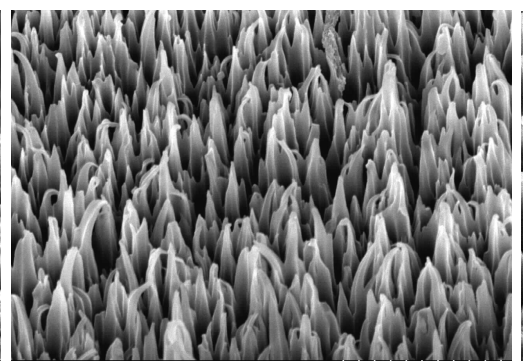

$2 \mu \mathrm{m}$

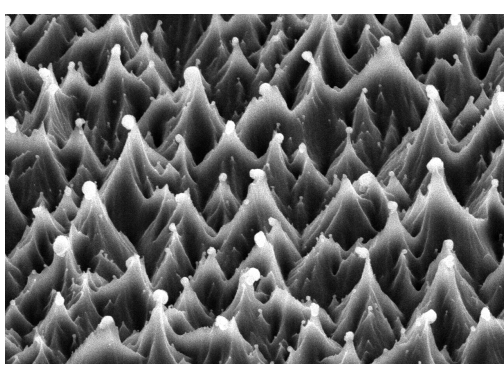

$5 \mu \mathrm{m}$

a. EOIM III Pyrolytic graphite

b. EOIM IIII Kapton $\mathrm{H}$

c. LDEF Teflon FEP

Figure 7. Scanning electron microscope images of pyrolytic graphite, polyimide Kapton and Teflon FEP exposed to directed LEO atomic oxygen on EOIM III or the LDEF.

It is interesting to note that carbon, in the form of single crystal class IIa diamond does not erode in atomic oxygen. This is thought to be due to the formation of a protective surface formed by closely spaced oxygen atoms that have replaced hydrogen atoms at the terminations of tetrahedrally-coordinated carbon on the external surface of diamond. The atomic oxygen erosion yield is not a meaningful number for materials such as most metals and silicones where the majority of the oxidation products are non-volatile.

The atomic oxygen erosion for fixed direction arrival with all materials that have volatile oxides is such that it causes the surfaces to erode to produce left-standing cones that represent a small fraction of the erosion depth. Examples of fixed direct atomic oxygen arrival textures for three materials (pyrolytic graphite, polyimide Kapton and Teflon FEP) from the Environmental Oxygen Interaction with Materials III (EOIM III) and Long Duration Exposure Facility (LDEF) space flight experiments are provided in Figure 7. 
The development of surface texture occurs whether or not the material is crystalline or amorphous and is a stochastic process which develops in a similar manner as to the meandering of rivers. Computational modeling of the surfaces also predicts the development of such surface cones [8 and 9]. Such surfaces have significant biomedical applications because they greatly increase cell attachment [8].

The length of cones increase with atomic oxygen fluence as the square root of the fluence [8]. The length of the cones relative to the average erosion depth for pyrolytic graphite, polyimide Kapton $\mathrm{H}$ and Teflon FEP are shown in Figure 8 at protected mesa locations. Calculated values for average cone height relative to the average erosion depth is provided in Table 2 for these flight samples, exposed at various atomic oxygen fluences on LDEF and EOIM III.

As can be seen in Table 2, the ratio of cone length to erosion depth appears to be material dependent. However, based on Reference 8, one would expect that for each material the ratio of cone length to erosion depth would decrease with atomic oxygen fluence.

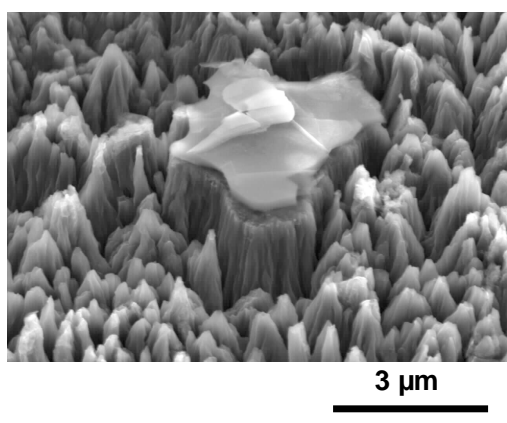

a. EOIM III Pyrolytic graphite

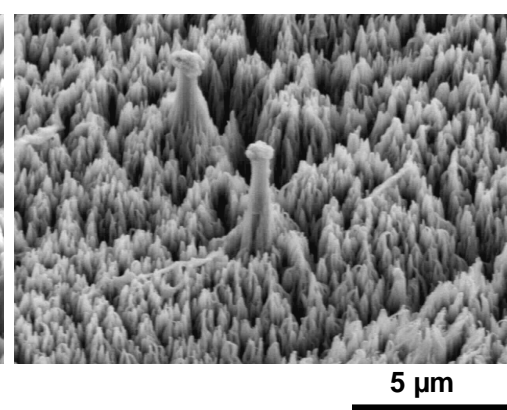

b. EOIM IIII Kapton H

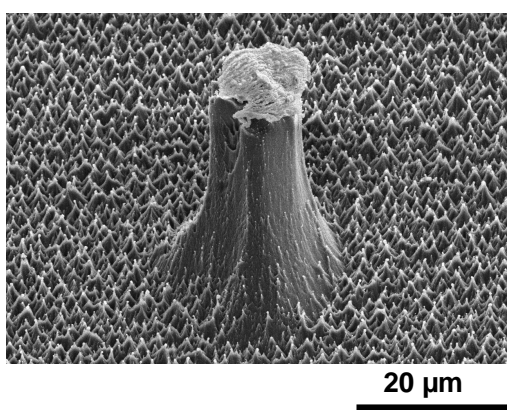

c. LDEF Teflon FEP

Figure 8. Scanning electron microscope images at protected mesas of pyrolytic graphite, polyimide Kapton and Teflon FEP exposed to directed LEO atomic oxygen on EOIM III or LDEF.

Table 2. Ratio of cone length to erosion depth as a function of fluence for various materials exposed to directed LEO atomic oxygen.

\begin{tabular}{|l|c|c|c|}
\hline \multicolumn{1}{|c|}{ Material } & $\begin{array}{c}\text { Ratio of average cone } \\
\text { length to erosion depth }\end{array}$ & $\begin{array}{c}\text { Space } \\
\text { Mission }\end{array}$ & $\begin{array}{c}\text { Atomic oxygen } \\
\text { fluence, atoms/cm }\end{array}$ \\
\hline Pyrolytic graphite & 0.60 & EOIM III & $2.3 \times 10^{20}$ \\
\hline Kapton H & 0.28 & EOIM III & $2.3 \times 10^{20}$ \\
\hline FEP Teflon & 0.07 & LDEF & $8.43 \times 10^{21}$ \\
\hline
\end{tabular}

\section{Protective Coatings}

The rate of erosion of polymers such as polyimide Kapton is sufficiently high that protective coatings which are durable to atomic oxygen are typically applied to prevent or reduce the rate of attack of underlying polymers. Such coatings typically consist of metal oxide or metal thin films which are atomic oxygen durable and prevent atomic oxygen from reaching the underlying polymer. A protective coating of 1300 Angstroms of sputter deposited $\mathrm{SiO}_{\mathrm{x}}$ (where $1.9<\mathrm{x}<2$ ) have been applied to the International Space Station solar array Kapton H blankets. The 
durability of such coatings is dependent upon the density and size of pin window and scratch defects in the protective coating. Vacuum deposited aluminum coatings contain much greater defect densities than sputter deposited $\mathrm{SiO}_{\mathrm{x}}$ coatings [10] thus allowing atomic oxygen to attack the polymer through undercutting oxidation at the microscopic defect sites as shown in Figure 9.

Surface particle contaminants and microscopic scratches, rills and cracks cause incomplete surface coverage of the protective film leading to atomic oxygen attack and undercutting at such sites. As atomic oxygen erodes at exposed polymer sites, the undercut cavities eventually connect leading to structural failure of the polymer. The density of defects is large for microscopically rough surfaces such as graphite epoxy composites. However the number of defects, in some cases, can be reduced from 180,000 defects $/ \mathrm{cm}^{2}$ to $\sim 1000 \mathrm{defects} / \mathrm{cm}^{2}$ through the application of surface leveling coatings [11].

The effects of LEO atomic oxygen undercutting can lead to complete loss of the underlying polymer if the defect density is sufficient and if the atomic oxygen is trapped when protective coatings are applied to both surfaces of the polymer. An on-orbit example is shown in Figure 10 where defects in vapor deposited aluminum coatings on both surfaces of a Kapton covering on the International Space Station solar array blanket boxes allowed atomic oxygen to become trapped, completely oxidizing the underlying Kapton [10].

A Monte Carlo computational model has been developed which simulates the interactions and resulting oxidative erosion of atomic oxygen impinging upon polymers [2, 9, and 10]. This model predicts that if just the space-exposed surface of the Kapton had been coated with vapor deposited aluminum, then there would have been less trapping of the atomic oxygen which would have tended to preserve the presence of the protected polymer, as shown in Figure 11.

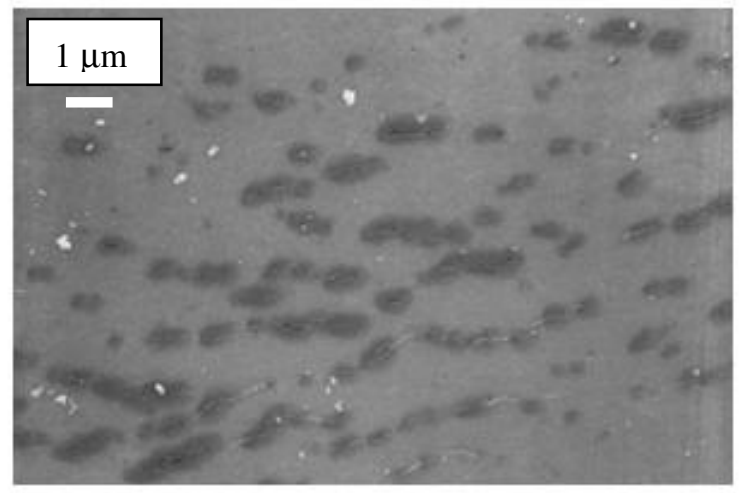

a. Prior to removal of $\mathrm{Al}$ coating

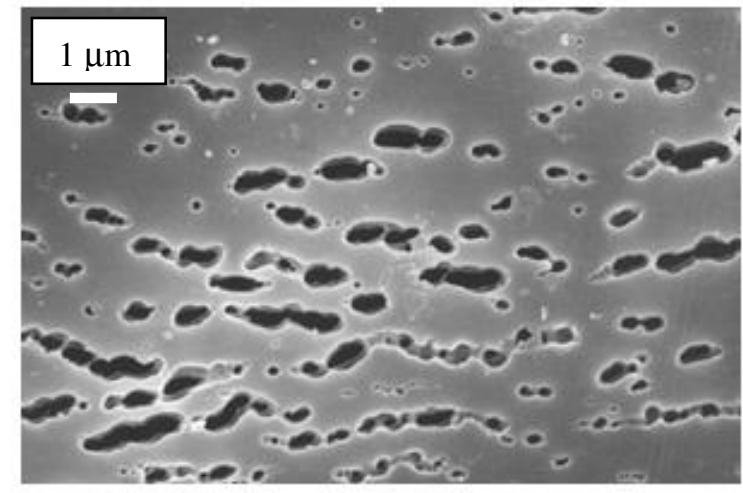

b. After chemical removal of Al coating

Figure 9. Atomic oxygen undercutting of scratches or cracks in aluminized Kapton retrieved from the Long Duration Exposure Facility. 


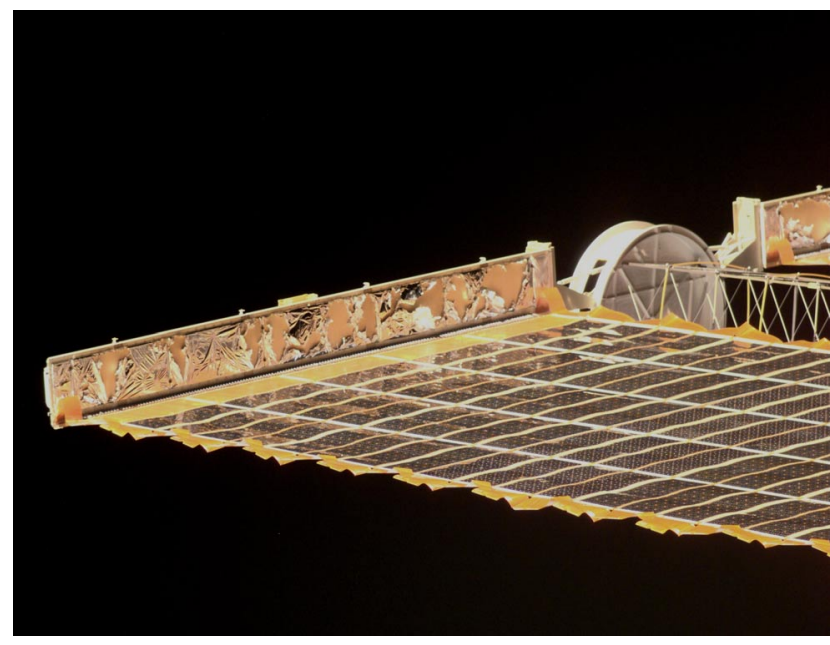

a. ISS solar array blanket box.

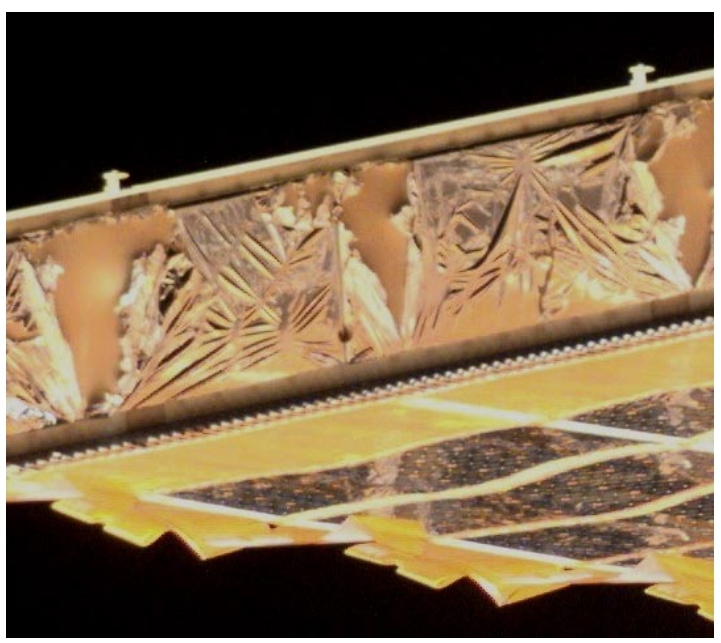

b. Close-up of damage.

Figure 10. International Space Station solar array blanket box after one year in LEO showing only the vacuum deposited aluminum coatings are present after complete oxidation of the underlying Kapton [10].

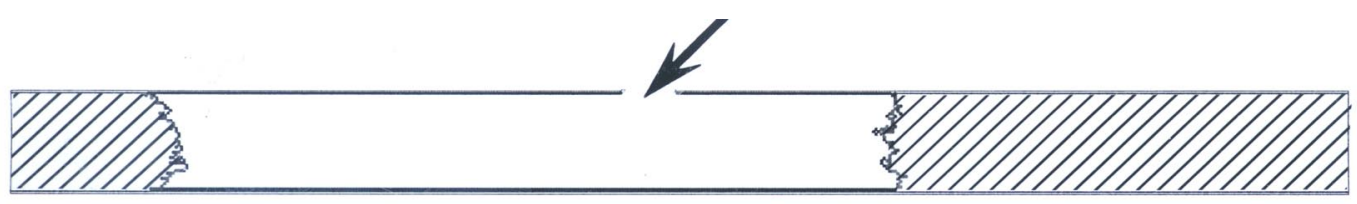

a. Prediction for protective coatings on both sides of the underlying Kapton.

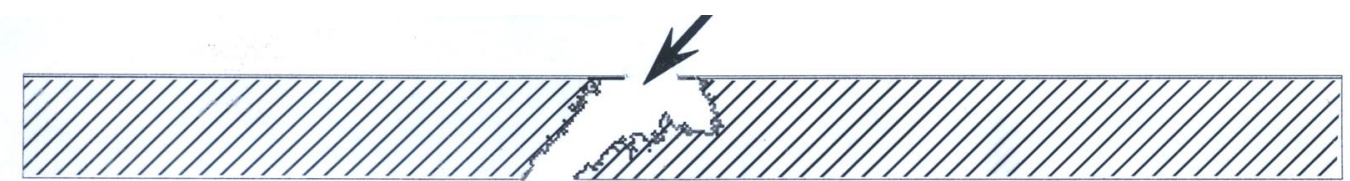

b. Prediction for a protective coating on only the space exposed side of the underlying Kapton.

Figure 11. Computational model predictions for protective coatings on either both sides of the underlying Kapton or on only the space exposed side of the underlying Kapton.

\section{Summary}

Atomic oxygen formed in low Earth orbit, has sufficient energy and flux to oxidize and erode most hydrocarbon polymers. There is a distribution in atomic oxygen arrival angle of attack caused by the orbital inclination, the Earth's co-rotation and the random thermal velocity of the hot Maxwellian atomic oxygen gas. The spatially random erosion processes causes the surfaces of all materials that have volatile oxidation products to become microscopically rough with cone structures that point in the direction of arriving atoms.

Atomic oxygen protective coatings of metal oxides and metals is a valuable means of reducing oxidative attack. However, microscopic particle contaminants, scratches, rills and cracks cause incomplete surface coverage of the protective film leading to atomic oxygen attack and undercutting at such sites. For this reason, coating only the atomic oxygen exposed side of a 
hydrocarbon polymer is desirable to prevent trapped atomic oxygen from severely undercutting the polymer substrate. The use of metal oxide protective coatings and surface leveling coatings can greatly reduce the density of defects in comparison to aluminized protective coatings.

\section{References}

1. NOAA, NASA and USAF, U.S. Standard Atmosphere, 1976, NASA TMX-74335, 1976.

2. Banks, B.A., de Groh, K.K., Rutledge, S.K., DiFilippo, F.J., "Prediction of In-Space Durability of Protected Polymers Based on Ground Laboratory Thermal Energy Atomic Oxygen," paper presented at the Third International Space Conference, Toronto, Canada, April 25-26, 1996.

3. Mende, S.B. Swenson, G.R., Clifton, K.S., Science, Vol. 225:191, 1984.

4. Banks, B.A., Rutledge S.K., "Low Earth Orbital Atomic Oxygen Simulation for Materials Durability Evaluation," Fourth European Symposium on Spacecraft Materials in Space Environment, Toulouse, France, 6-9, September, 1988, pp. 372-392, 10.

5. Bruce A. Banks, S.K. Rutledge, Phillip E. Paulsen and Thomas J. Steuber, "Simulation of the Low Earth Orbital Atomic Oxygen Interaction With Materials by Means of an Oxygen Ion Beam," Presented at the 18th Annual Symposium on Applied Vacuum Science and Technology, Clearwater Beach, Florida, February 6-8, 1989; NASA TM-101971, 1989.

6. Bruce A. Banks, "The Use of Fluoropolymers in Space Applications" in Modern Fluoropolymers, Edited by John Scheirs, (pp. 103-113), Chapter 4, John Wiley \& Sons Ltd, 1997.

7. "Prediction of Erosion of Polymer-Based Materials by Atomic Oxygen in LEO," Integrity Testing Laboratory Inc. Final Report, GRC Contract \#C-72917-G, 1998.

8. Banks, B.A., Rutledge, S.K., Chan, A., Sahota, M., "The Development of Surface Roughness and Implications for Cellular Attachment in Biomedical Applications," NASA/TM-2001-211288, presented at the 2001 Fall Meeting of the Materials Research Society, Boston, MA, November 26-30, 2001.

9. Banks, B.A., Stueber, T.J., Snyder, S.A., Rutledge, S.K., and Norris, M.J., “Atomic Oxygen Erosion Phenomena," presented at the American Institute of Aeronautics and Astronautics, Defense and Space Programs Conference, Huntsville, AL, Sept. 23-25, 1997.

10. Banks, B., Lenczewski, M., and Demko, R., "Durability Issues for the Protection of Materials from Atomic Oxygen Attack in Low Earth Orbit," NASA/TM-2002-211830, August 2002, Paper IAC-02-1.5.02, presented at the 53 International Astronautical Congress, The World Space Congress-2002, Houston TX, October 10-19, 2002.

11. D.A. Jaworske, K.K. de Groh, G. Podojil, T. McCollum, and J. Anzic, "Leveling Coatings for Reducing the Atomic Oxygen Defect Density in Protected Graphite Fiber Epoxy Composites," Journal of the IES (Institute of Environmental Sciences), May/June 1994, Vol. XXXVII, No. 3, pp. 26-31. 


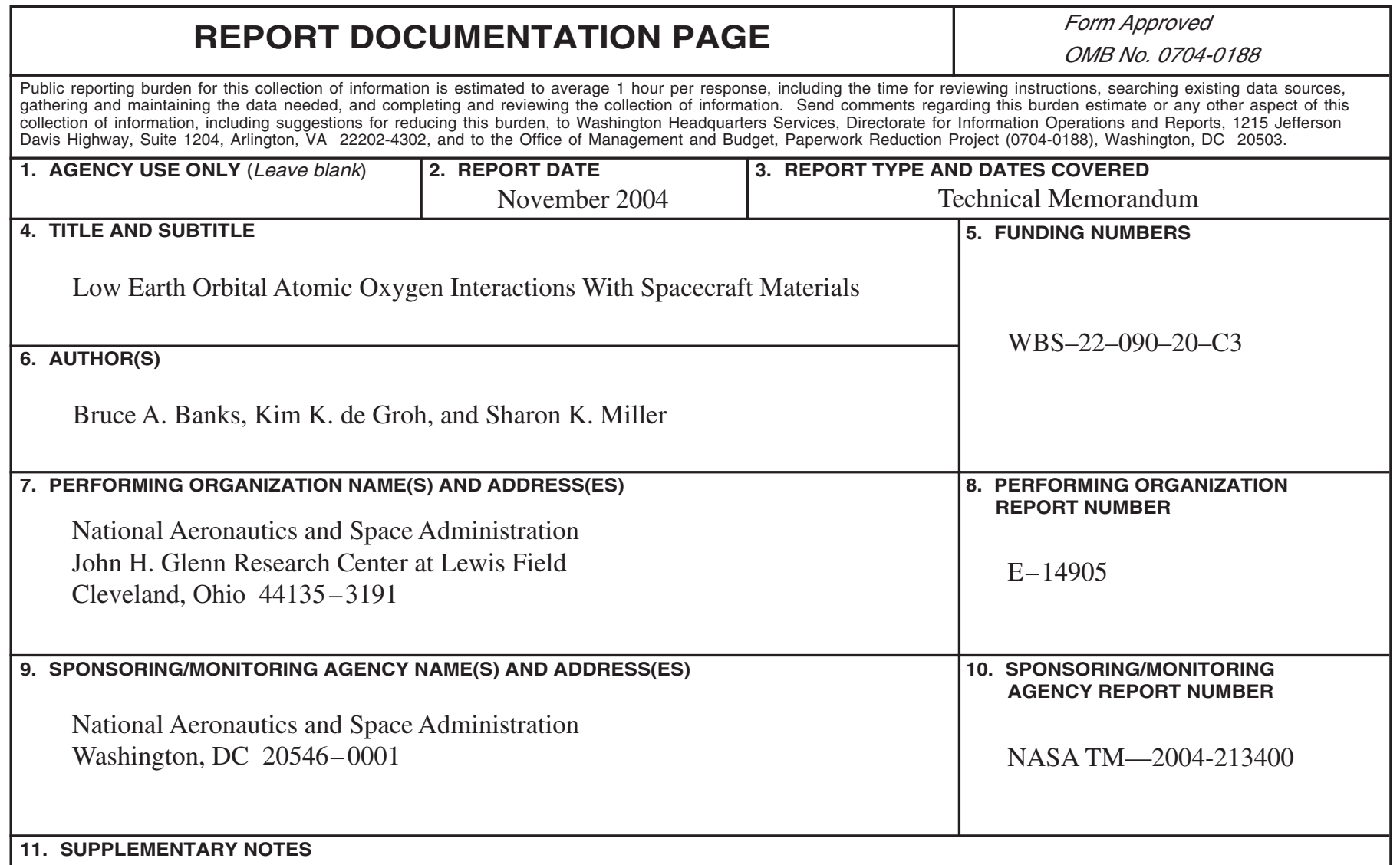

Prepared for the 2004 Fall Meeting sponsored by the Materials Research Society, Boston, Massachusetts,

November 29-December 3, 2004. Responsible person, Bruce A. Banks, organization code RPY, 216-433-2308.

\begin{tabular}{|l|l|l|l|l}
\hline 12a. DISTRIBUTION/AVAILABILITY STATEMENT & 12b. DISTRIBUTION CODE
\end{tabular}

Unclassified - Unlimited

Subject Category: $31 \quad$ Distribution: Nonstandard

Available electronically at http://gltrs.grc.nasa.gov

This publication is available from the NASA Center for AeroSpace Information, 301-621-0390.

13. ABSTRACT (Maximum 200 words)

Atomic oxygen, formed in Earth's thermosphere, interacts readily with many materials on spacecraft flying in low Earth orbit (LEO). All hydrocarbon based polymers and graphite are easily oxidized upon the impact of $\sim 4.5 \mathrm{eV}$ atomic oxygen as the spacecraft ram into the residual atmosphere. The resulting interactions can change the morphology and reduce the thickness of these materials. Directed atomic oxygen erosion will result in the development of textured surfaces on all materials with volatile oxidation products. Examples from space flight samples are provided. As a result of the erosive properties of atomic oxygen on polymers and composites, protective coatings have been developed and are used to increase the functional life of polymer films and composites that are exposed to the LEO environment. The atomic oxygen erosion yields for actual and predicted LEO exposure of numerous materials are presented. Results of in-space exposure of vacuum deposited aluminum protective coatings on polyimide Kapton indicate high rates of degradation are associated with aluminum coatings on both surfaces of the Kapton. Computational modeling predictions indicate that less trapping of the atomic oxygen occurs, with less resulting damage, if only the space-exposed surface is coated with vapor deposited aluminum rather than having both surfaces coated.

\begin{tabular}{|l|l|l|}
\hline 14. SUBJECT TERMS \\
Atomic Oxygen; low Earth orbit; Erosion yield \\
\hline $\begin{array}{c}\text { 17. SECURITY CLASSIFICATION } \\
\text { OF REPORT } \\
\text { Unclassified }\end{array}$ & $\begin{array}{c}\text { 18. SECURITY CLASSIFICATION } \\
\text { OF THIS PAGE } \\
\text { Unclassified }\end{array}$ & $\begin{array}{c}\text { 19. SECURITY CLASSIFICATION } \\
\text { OF ABSTRACT } \\
\text { Unclassified }\end{array}$ \\
\hline
\end{tabular}



